\title{
Measuring Strategies to Cope with Boredom in Spanish Speaking Population: A
}

\section{Study with Argentinean University Students}

\author{
Sánchez Rosas, Javier \& Juan Bedis \\ Laboratory of Psychological and Educational Assessment, Faculty of Psychology, National University of \\ Cordoba, Argentina
}

Please address correspondence concerning this article to Javier Sánchez Rosas, Laboratory of Psychological and Educational Assessment, Faculty of Psychology, National University of Córdoba, Argentina. Enrique

Barros and Enfermera Gordillo, 5000, Córdoba, Argentina.

E-mail: jsanchezrosas@psyche.unc.edu.ar

\begin{abstract}
A study was conducted in order to validate the Boredom Coping Scales and test its psychometric properties on a sample of Argentinean university students (namely BCS-AR). The BCS-AR, adapted into Spanish, was applied to a sample of students at National University of Córdoba and the National Technological University $(\mathrm{N}=250)$. Internal consistency was estimated through Cronbach's alpha $(\alpha)$. Evidence about the test's internal structure was obtained from evaluating and comparing three measurement models for boredom coping strategies. Criterion validity evidence was provided by bivariate correlations with task value, attention, academic boredom and enjoyment. The scales showed acceptable internal consistency scores (between $\alpha=.69$ and $\alpha=.92)$. The four factor model showed an acceptable fit $(\chi 2 / \mathrm{df}=1.65, \mathrm{CFI}=.95$, $\mathrm{GFI}=.91$, RMSEA $=0.051)$. Test criterion evidence partially corresponded to the expected results. Results are discussed within the framework of control-value theory of achievement emotions and boredom coping.
\end{abstract}

Keywords: academic boredom, boredom coping, enjoyment, task value, attention, validation

Resumen. Se realizó un estudio para validar las Escalas de Afrontamiento del Aburrimiento y analizar sus propiedades psicométricas en una muestra de estudiantes universitarios de Argentina (BCS-AR). La BCS-AR, adaptada al español, se aplicó a una muestra de estudiantes en la Universidad Nacional de Córdoba y la Universidad Tecnológica Nacional $(\mathrm{N}=$ 250). La consistencia interna se estimó mediante el alfa de Cronbach $(\alpha)$. Se obtuvo evidencia de la estructura interna al evaluar y comparar tres modelos de medición de estrategias de afrontamiento del aburrimiento. Se aportó evidencia de validez criterio mediante correlaciones bivariadas con valor de la tarea, atención, aburrimiento y disfrute académico. Las escalas demostraron valores aceptables de consistencia interna $(\alpha=.69$ hasta $\alpha=.92)$. El modelo de cuatro factores relacionados demostró un ajuste aceptable $(\chi 2 / \mathrm{df}=1.65, \mathrm{CFI}=.95, \mathrm{GFI}=.91, \mathrm{RMSEA}=0.051)$. La evidencia test criterio se correspondió parcialmente con los resultados esperados. Se discuten los resultados en el marco de la teoría control-valor de las emociones de logro y del afrontamiento del aburrimiento.

Palabras clave: aburrimiento académico, afrontamiento del aburrimiento, disfrute, valor de la tarea, atención, validación 


\section{INTRODUCTION}

The concept of coping strategies appeared three decades ago, emerging from research on stress (Lazarus \& Folkman, 1985). Studies in this field intend to examine people's reactions in the face of stressful events (Figueroa \& Cohen Imach, 2006; Vázquez Valverde, Crespo López, \& Ring 2003). In general lines, the term coping strategies refers to thoughts and actions that enable people to handle difficult situations (Vázquez Valverde et al., 2003). In line with these thoughts, Lazarus and Folkman (1985) define it as those constantly-changing cognitive and behavioral efforts which aim at managing specific external and/or internal demands deemed as exceeding or surpassing of an individual's resources.

Following the classification proposed in a model addressing stress coping (Holahan, Moos, \& Schaefer, 1996), Nett, Goetz and Daniels (2010) developed the Boredom Coping Scales, which allow identifying four strategies used by students to handle boredom in class. The scales have been adapted to Chinese (Tze, 2011), Canadian and Turkish (Eren, 2013) populations, obtaining good reliability and validity indices. In addition, they proved to be useful in predicting self-efficacy for self-regulated learning (Tze, 2011), student engagement (Eren, 213), boredom, enjoyment, anxiety, effort, interest (Nett et al., 2010), as well as in differentiating subject groups according to the strategies they use (Nett et al., 2010; Tze, 2011).

This research consists in the validation of the Boredom Coping Scales in a sample of Argentinean university students (namely BCS-AR). Specifically, it provides evidence on internal consistency, internal structure and criterion validity for the scales.

\section{The control-value theory of achievement emotions: Boredom}

Boredom is an emotion that arises in achievement situations such as studying a particular subject or attending classes. It is understood as a negative emotion, since it is experimented as an unpleasant feeling; as well as a behavior-deactivating emotion, since it reduces physiological activation. This emotion contains specific components such as affective (unpleasant feelings), cognitive (time passing slowly feelings, distraction), physiological (low activation level), bodily-expressive (low body posture, facial expression,

monotonous tone of voice) and motivational components (a drive for abandoning or changing the situation) (Pekrun, Goetz, Daniels, Stupinsky, \& Perry 2010). 
This research is conducted within the framework provided by the control-value theory of achievement emotions framework (Pekrun, 2006). This theory implies that two main factors determine boredom emergence: control appraisals (e.g., skill) and value appraisals (e.g., importance, utility). Therefore, boredom is experienced when the activity value is low (Goetz, Pekrun, Hall, \& Haag, 2006; González, Paoloni, \& Rinaudo, 2013; Nett et al., 2010; Pekrun et al., 2010; Tze, 2011; Vodanovich, Weddle, \& Piotrowsky, 1997); and when the activity control is either high or low (Acee et al., 2010; Pekrun, Goetz, Titz, \& Perry, 2002; Pekrun et al., 2010), though more frequently when it's low (Perry, Hladkyj, Pekrun, \& Pelletier, 2001).

\section{Boredom-related coping strategies}

Nett et al. (2010) developed the Boredom Coping Scales following the classification proposed by Holahan et al. (1996) in their model about stress coping; and validated its implementation in the academic emotions domain, in order to elucidate what students do and think when bored.

This model identifies two dimensions underlying coping strategies: (1) Orientation: It divides the strategies according to their objective into approach-oriented (trying to address the boredom-generating situation), and avoidance-oriented (withdrawing from the boring situation) strategies; (2) Action: It divides the strategies according to their nature into cognitive and behavioral strategies.

The possible combinations of these dimensions delimit four boredom-coping strategies:

1. Cognitive-approach strategies involve a student's voluntary change on the way they perceive the situation. An example would be a student that, bored in a Physics class, remembers the value of paying attention in class so as to pass the test.

2. Cognitive-avoidance strategies refer to making use of cognitive resources with the aim of distracting oneself from a boredom-generating situation. Many students carry out this strategy by resorting to fantasy, or thinking about something else when they are in class.

3. Behavioral-approach strategies imply efforts to change the boredom-generating situation itself. Some of the most common strategies consist in asking the teacher for more 
interesting tasks, proposing alternatives to the assignment, or simply informing the teacher about the situation.

4. Finally, behavioral-avoidance strategies refer to actions the student takes in order to disengage from the boring situation, looking for some distraction, such as talking to a classmate or playing on their mobile phones.

\section{Boredom, boredom-coping strategies and task value}

Little research has been dedicated to boredom, especially in achievement contexts, despite the fact that its effects can be detrimental to students. For instance, boredom can be considered an antecedent for behaviors like missing classes or leaving before the class is over (Triado-Ivern, Aparicio-Chueca, Guardia-Olmos, \& Jaría Chacón, 2009), reduction of task-related attention and engagement in irrelevant thoughts (Pekrun et al., 2010), impairment of self-regulated learning (Tze, 2011) and decreases on motivation and academic performance (González et al., 2013).

A great deal of research (González et al., 2013; Mann \& Robinson, 2009; Nett et al., 2010; Pekrun et al., 2010; Tze, 2011; Tze, Daniels, Klassen, 2015) highlights a negative correlation between the frequency of boredom in class and subsequent student's performance. The influence of boredom on performance can be presented as an indirect effect. Mann and Robinson (2009) explain that it may be due to the fact that bored students are prone to leave the class before it ends or simply miss it (Massingham \& Herrington, 2006; Triado-Ivern et al., 2009). Perceived task value could be related to boredom and to the choices students make about in relation to remain engaged in the current task (Eccles, 2005; Pekrun et al., 2010).

Task value refers to student's perceived interest, importance and utility regarding learning materials and contents (Pintrich, Smith, García, \& Mckeachie, 1993). The value of an achievement activity instigates positive emotions such as enjoyment (Pekrun, Elliot, \& Maier, 2006), and lack of it promotes negative emotions, such as boredom (Pekrun, 2006). This affirmation is supported by Pekrun et al. (2010), whom evaluated the correlation between boredom and value in five studies, finding in all cases negative relations for these constructs. In particular, it was confirmed that lack of value is an antecedent of experiencing boredom in class.

Regarding boredom coping strategies, their correlations with activity value are 
diverse. In Nett et al. (2010), cognitive approach shows a positive correlation with value, while behavioral approach shows no correlation and cognitive and behavioral avoidance present negative and weak correlations. The authors posit that cognitive-approach strategies are the most adaptive ones. This is due to the fact that they predict positive academic outcomes such as increased students' performance and engagement, low boredom and anxiety levels as well as high levels for enjoyment.

Cognitive-approach strategies' main characteristic is a change in the situation's perception resulting from a positive reappraisal. The student carries out a cognitive effort in order to increase the value that the activity represents to him or herself so as to change the situation's perception as well. In this sense, Eren's studies (2013) show that class perceived instrumentality positively correlates with this kind of strategies. This means that if a student considers a class to be useful to accomplish his personal goals, when bored he will resort to strategies that allow him to link the activity back with its corresponding value.

\section{Boredom, Boredom-coping and Attention}

Attention is an essential resource when it comes to successfully learning or performing in learning contexts. An attention deficit may cause students to have a poor academic performance. Pekrun et al. (2010) argued that bored students tend to pay attention to stimuli regarded as more interesting, or to become distracted by thoughts unrelated to the class, which eventually has an influence on their academic performance. According to these studies, boredom is strongly related to attention problems. Individuals who suffer from boredom experience a progressive loss of attention, which subsequently results in a lack of concentration, which results in lack of concentration, distraction and activity-irrelevant thoughts.

According to Vogel-Walcutt, Fiorella, Carper and Schatz (2012), boredom occurs when an individual experiences a neurological state of low arousal concurrently with a psychological state of dissatisfaction, frustration, or disinterest in response to the low arousal. This neurophysiologic low arousal is defined in terms of under-stimulation, activity disconnection, and desire for sensory stimuli, and mental state of inactivity or prolonged exposure to monotony. Boredom could be reduced by increasing the arousal through implementation of adequate teaching strategies (Rosegard \& Wilson, 2013), teacher enthusiasm (Wood, 1998), and teacher attitudes that promote student engagement 
(Sánchez Rosas, Takaya, \& Molinari, 2016, in press).

Nett et al. (2010) and Tze (2011) assert that positive reappraisal of a boring situation (i.e. cognitive approach) not only improves attention readdressing it to the important material, but also increases activity value. On the contrary, avoidance strategies (either cognitive or behavioral) would impair attention in class since they imply diverting it towards more interesting stimuli, unrelated to the activity.

\section{Boredom, Boredom-coping and Other Achievement Emotions}

Empirical evidence (González, Donolo, \& Rinaudo, 2009; González et al., 2013; Nett et al., 2010; Pekrun, Goetz, Frenzel, Barchfeld, \& Perry, 2011) shows a negative correlation between boredom and enjoyment. This might be explained by the fact that boredom mitigation gives rise to the occurrence of more positive emotions. In addition, enjoyment is presented as conceptually opposed to boredom since it also constitutes an activity-related emotion but its perceived value and control are high (Pekrun, 2006).

Pekrun et al. (2010) posit that while feeling bored, students simultaneously experience other negative emotions such as disappointment, despair (Goetz et al., 2013; Pekrun et al., 2011), anger, shame (Goetz et al., 2013; González et al., 2009; Pekrun et al., 2011) and anxiety (Nett et al., 2010).

Boredom-coping strategies yield diverse correlations with achievement emotions. In Nett et al. study (2010), cognitive approach yielded a positive correlation with enjoyment, effort, interest and value; and a negative one with boredom. The remaining strategies correlated positively with boredom and anxiety, and negatively with enjoyment, effort, interest and value. Tze (2011) replicated some of these results, obtaining a negative correlation between cognitive approach and boredom with two samples of Chinese and Canadian university students. On the other hand, the remaining strategies yielded no correlation, except for behavioral avoidance that positively correlated with boredom in the Chinese sample.

\section{The Current Study}

At this time, there exist three validations of the Boredom Coping Scales carried out with university population in China, Canada (Tze, 2011), and Turkey (Eren, 2013) besides the original study carried out on a sample of German primary students (Nett et al. 2010). In 
all cases, the instrument proved to have good psychometric features of internal structure, reliability and criterion validity. For these reasons, it constitutes a trustworthy instrument, since there is no evidence about other instruments for measurement of boredom coping in Spanish. Furthermore, the insights into this construct are novel and few; so we expect this study will shed light over an emerging area within educational psychology.

The aim of this work is to validate the BCS-AR to be used among university students in Argentina. Studies on internal consistency, internal structure and criterion validity will be carried out.

\section{METHOD}

\section{Participants}

The sample consisted of 250 Argentinian undergraduate students belonging to fifteen careers at National Technological University (33.6\%) and National University of Córdoba (66.4\%). Participants' ages oscillated between 17 and 39 years $(\mathrm{M}=19.86, \mathrm{DS}=$ 2.19). The questionnaires were administered in Mathematical Analysis I and II courses, which were functioning in two modalities: theoretical and practical classes.

\section{Measures}

Boredom Coping Scales-Argentine (BCS-AR). The Goetz and Nett's (2008) questionnaire comprises four scales measuring coping categories (cognitive approach, behavioral approach, cognitive avoidance, behavioral avoidance). Each scale features five items to be answered in Likert format ranging from (1) strongly disagree to (5) strongly agree. The items begin with a common statement (when I am bored in class...) followed by a coping strategy (e.g., I try to think in the significance of this class). In the original study (Nett et al., 2010), the Cronbach's alphas proved to be satisfactory: cognitive approach $=$ .91 , behavioral approach $=.83$, cognitive avoidance $=.83$, and behavioral avoidance $=.92$. While this questionnaire is useful to assess boredom coping strategies in math class, it is not specific of this domain, being able to be applied in other subjects by changing the main consign.

Boredom and Enjoyment in Class. Two scales from the Achievement Emotions Questionnaire-Argentine were used (Sánchez Rosas, 2015a). The boredom in class scale comprises eleven items (the class is so boring that I feel like leaving, $\alpha=.90$ ) and the 
enjoyment in class scale, ten items (I enjoy attending this class, $\alpha=.87$ ). This instrument measures the frequency of this kind of emotions in a Likert scale which ranges from (1) never to (5) always.

Task Value. The Task Value Scale designed by Pintrich et al. (1993) was administered, which evaluates perceived interest, importance and utility of the learning materials and contents. It comprises six items (I think that what I learn in this subject will be useful in others) and showed an internal consistency of .79. Answers are collected in the Likert scale ranging from (1) totally disagree to (5) fully agree. This scale showed criterion validity with respect to emotions in university students from Córdoba, Argentine (Sánchez Rosas, Piotti, Sánchez, Pereira, \& Debat, 2011).

Attention in class. A one-dimensional scale composed ad hoc was used. It addresses three aspects comprised in this construct: concentration capacity, irrelevant thoughts, and attention. The scale comprises six items, three of those items are reverse-coded (e.g., I become unfocused) and the remaining three are directly formulated (e.g., I follow with attention what is being explained). The answers are provided on a Likert scale ranging from "never" (1) to "always" (5). In the process of analysis the first three items were recodified. The scale's unidimensionality was evaluated through exploratory factor analysis and internal consistency obtaining adequate results $(\mathrm{KMO}=.83 ; 55 \%$ of explained variance and factor loading $>.68 ; \alpha=.83)$.

\section{Procedure}

Initially, the scales were directly translated from English into Spanish with assistance of an official translator. English and Spanish versions were administered to a sample of bilingual students $(\mathrm{N}=27)$ in two separate sessions with an interval of one week. The questionnaires were administered personally, after explaining the participants the aims of the study and the fact that their answers would be anonymous and used only for research purposes.

Both sessions' scores were correlated, producing moderate and high Spearman coefficients. Additionally, a Student's test for related samples showed that there were no significant differences between both sample means. As a result, the Spanish version proved to be equivalent to the original English scale. Subsequently, the scale's psychometric properties were analyzed. 


\section{Data analysis}

Data were analyzed to ensure compliance with statistical assumptions of (univariate and multivariate) normal distribution, correlations linearity, multicollinearity and absence of outliers, obtaining suitable results (George \& Mallery, 2007).

Internal consistency was assessed through Cronbach's alpha. For item-total correlation .5 is set as the minimum acceptable (Hair, Anderson, Tatham, \& Black, 1999). As for Cronbach's alpha, it will be categorized in accordance with the following scale: $>.9$ excellent, $>.8$ good, $>.7$ acceptable, $>.6$ questionable, $>.5$ poor and $<.5$ unacceptable (George \& Mallery, 2007).

In order to assess the questionnaire's internal structure, three boredom-coping models were evaluated and compared through confirmatory factor analyses (CFA) (See Figure 1). In addition, the following indexes were used to assess the model's goodness of fit to the data: chi-squared distribution with degrees of freedom $(\chi 2 / \mathrm{df})$, comparative fit index (CFI), root mean square error of approximation (RMSEA) and global fit index (GFI). The following criteria were implemented to assess the model's goodness of fit: $\chi 2 / \mathrm{df} \leq 2.0$ (Hair et al., 1999), CFI $\geq .90, \mathrm{GFI} \geq .90$, (Hu \& Bentler, 1998), RMSEA $\leq 0.06$ (Arias, 2008).

Modification indexes were analyzed and the implementation of re-specifications was contemplated, as long as they had theoretical founding and would improve fit indexes.

The evaluated models were the following (See Figure 1): One first model in which all indicators score under a single boredom-coping factor (unidimensional model); a second model consisting of four first order factors matching each questionnaire scale, and one second order factor with the purpose of accounting for variance in all four dimensions. The third model comprises these four correlated first order factors, in which indicators score each in its corresponding factor (oblique model). The best fit indexes are expected for this third model, since it has been previously supported by empirical evidence (Eren, 2013; Nett et al., 2010; Tze, 2011).

Finally, criterion validity evidence was obtained from bivariate correlations among boredom-coping strategies and achievement emotions (enjoyment and boredom), task value and attention. Pearson coefficients of correlation (r) were considered: from .10 to .29, weak; from .30 to .49 moderate; and from .50 onwards, robust (Aron \& Aron, 2001).

Data were analyzed through the software IBM SPSS Amos 19 (Arbuckle, 2010). 

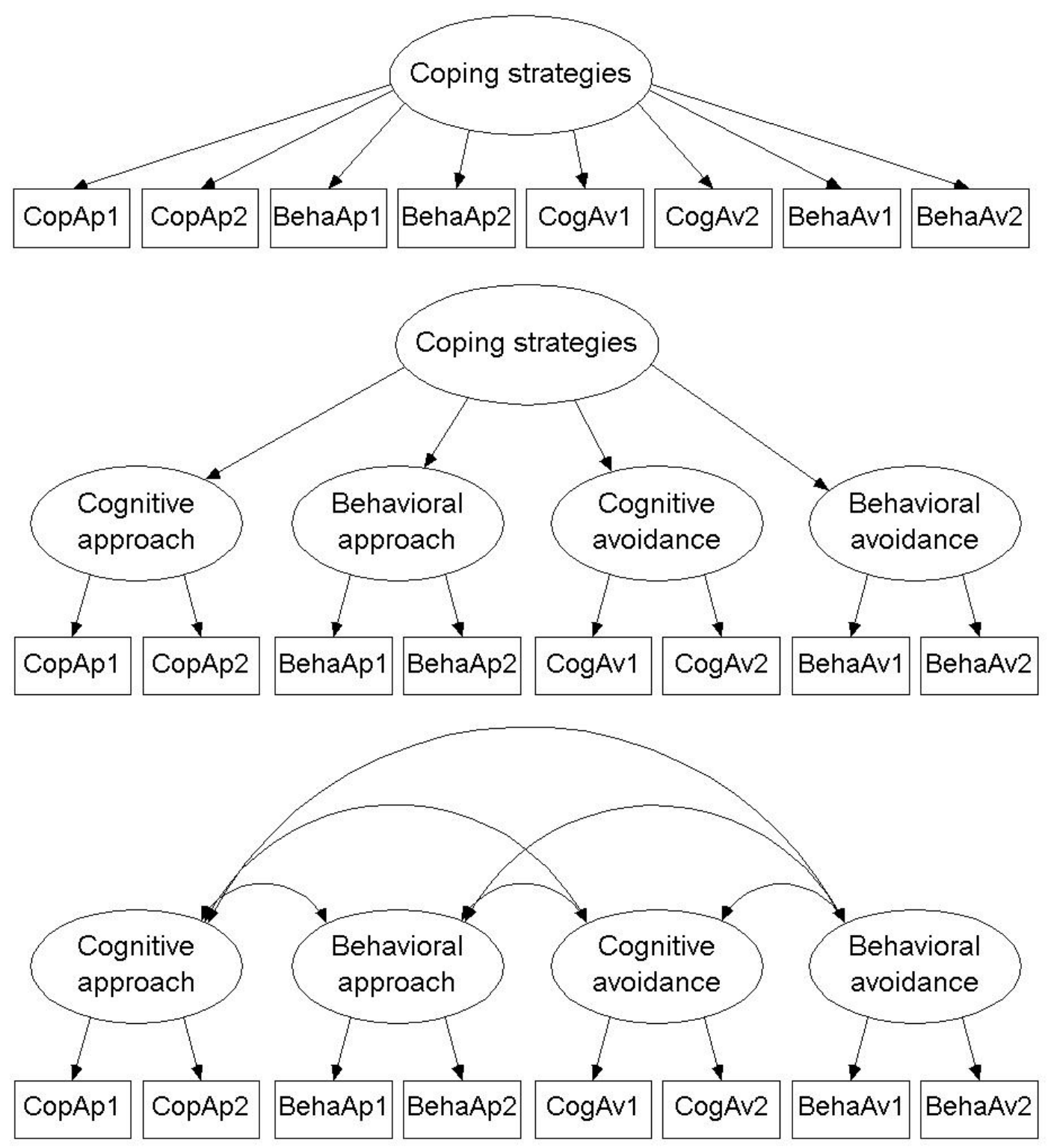

Figure 1. Assessed boredom-coping strategies models.

\section{RESULTS}

\section{Descriptive Statistics, Correlations and Scales' Reliability}

After assessing data adequacy, a descriptive analysis was carried out, by calculating means, standard deviation, asymmetry and kurtosis indexes for each item.

The sum of all items within each scale was used to obtain "CogAp", "BehaAp", "CogAv" and "BehaAv" variables; these variables were also correlated so as to observe the 
degree of interrelation among the scales (Table 1). Some similarities were found between these results and Nett and colleagues' (2010) study results, which are discussed below.

Cronbach's alpha was acceptable for the cognitive-approach scale, and excellent for the behavioral-approach scale. The cognitive-avoidance scale produced a marginally acceptable alpha (Table 1). According to Hair and colleagues' (1999) recommendations, item-total correlations were generally acceptable, with the exception of some items within the cognitive-approach and cognitive-avoidance scales. Nevertheless, two facts should be taken into account: On one hand, there are studies (De Castro Marzo, 2011) which prove the usefulness of maintaining these items, whenever their potential elision reduces the total scale index. On the other hand, some authors (Frías Jiménez, González Arias, \& González Laucirica, 2013) consider that, in a scale's validation context, an item-total correlation coefficient of .4 is acceptable.

Table 1. Correlations among BCS-AR and comparison with Nett et al. (2010)

\begin{tabular}{lcccc}
\hline & $\mathbf{1}$ & $\mathbf{2}$ & $\mathbf{3}$ & $\mathbf{4}$ \\
\hline 1. Cognitive Approach & $19.20(3.24) / .73$ & $.05^{*}$ & $-.21^{* *}$ & $-.39^{* *}$ \\
2. Behavioural Approach & .10 & $8.31(3.16) / .78$ & $.31^{* *}$ & $.21^{* *}$ \\
3. Cognitive Avoidance & $-13^{*}$ & $.31^{* *}$ & $14.50(4.08) / .69$ & $.47^{* *}$ \\
4. Behavioural Avoidance & $-.26^{*}$ & $.13^{*}$ & $.13^{*}$ & $14.26(5.61) / .92$ \\
\hline
\end{tabular}

Note: ${ }^{*} p .01 ;{ }^{* *} \mathrm{p}<.001$. Values over the diagonal pertain to Nett et al. (2010); below it, values pertaining to this study. The diagonal displays the values for mean, standard deviation and Cronbach's alpha.

\section{Validity Analysis: Internal Structure}

According to $\mathrm{Hu}$ and Bentler (1998), and Arias' (2008) guidelines, factor analysis results for all three models were not satisfactory (Figure 1). Consequently, some respecifications were implemented after reviewing modification indexes. The suggestion to correlate the same errors in both, hierarchical and oblique models was observed. At the moment of reviewing these items' content, a significant overlapping was observed. In the unidimensional model, modification indexes suggested to correlate all measuring errors inside each scale. It is important to note that correlated errors corresponded to items within the same scales, and there were no instances of correlation among items from different scales. With the aim of achieving an accurate comparison, these errors were correlated in the three models. 
Owing to this, fit indexes significantly improved in the three models. Even so, the oblique model (see Figure 2) obtained the best fit indexes (Arias, 2008; Hu \& Bentler, 1998), which are: $X^{2}(157, \mathrm{~N}=250)=259.101, p=.000 ; X^{2} / d f=1.65, \mathrm{CFI}=.95, \mathrm{GFI}=$ $.91, \mathrm{RMSEA}=0.051$.

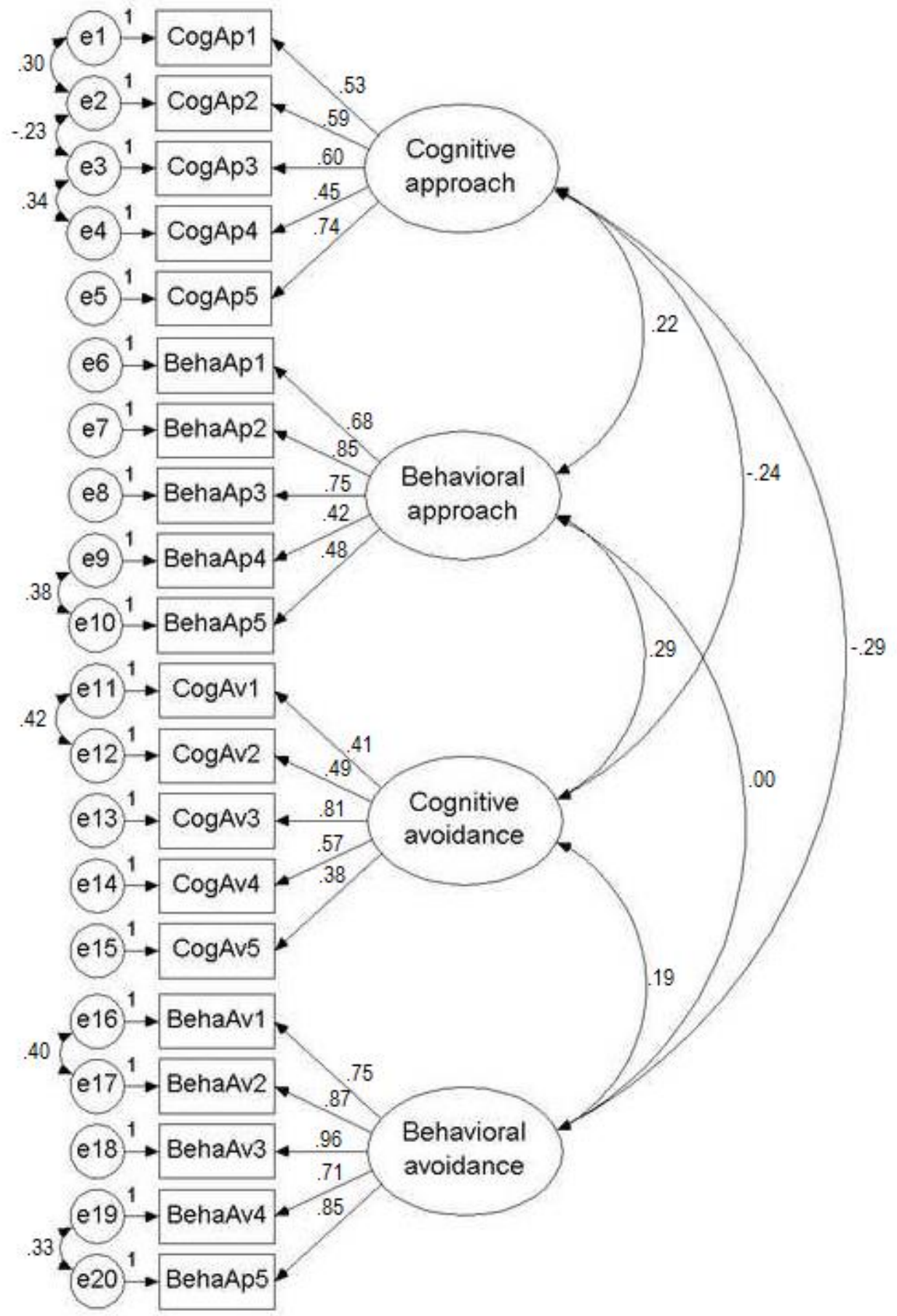

Figure 2. BCS-AR: Re-specified oblique model. 
In table 2, results obtained by all three models, original and re-specified, are compared.

Table 2. Models' fit indexes comparison, with and without re-specifications

\begin{tabular}{lcccc}
\hline & X2/df & CFI & GFI & RMSEA \\
\hline Unidimensional Model & 6.89 & .51 & .62 & .154 \\
Re-specified Unidimensional Model & 4.98 & .68 & .72 & .126 \\
Hierarchical Model & 2.86 & .85 & .84 & .086 \\
Respecified Hierarchical Model & 1.75 & .94 & .90 & .055 \\
Four Correlated Factors Model & 2.74 & .86 & .84 & .084 \\
Four Correlated Factors Respecified Model & 1.65 & .95 & .91 & .051 \\
\hline
\end{tabular}

In table 3, fit indexes for the oblique model in all existing studies are summarized.

Table 3. Fit indexes for the oblique model in the original and adapted versions

\begin{tabular}{cccccc}
\hline & X2 & X2/df & RMSEA & CFI \\
\hline \multirow{2}{*}{ Original } & $\begin{array}{c}\text { Nett et al. } \\
(2010)\end{array}$ & 514.71 & 3.13 & 0.047 & .96 \\
\hline \multirow{2}{*}{ Adapted } & Tze (2011) & & & \\
& Canada & 244.60 & 1.51 & 0.065 & .95 \\
& $\begin{array}{c}\text { Tze (2011) } \\
\text { China } \\
\text { Versions }\end{array}$ & 300.86 & 1.86 & 0.062 & .93 \\
& $\begin{array}{c}\text { Eren (2013) } \\
\text { Turkey } \\
\text { Bedis (2015) } \\
\text { Argentina }\end{array}$ & 420.93 & 2.59 & - & .97 \\
& 259.101 & 1.65 & 0.051 & .95 \\
\hline
\end{tabular}

\section{Validity Analysis: Criterion Validity}

Criterion validity was assessed through bivariate correlations among the diverse boredom-coping strategies and achievement emotions (boredom and enjoyment), task value and attention (see table 4). 
Table 4. Bivariate correlations among BCS-AR and criterion variables

\begin{tabular}{lcccccccc}
\hline & $\mathbf{1}$ & $\mathbf{2}$ & $\mathbf{3}$ & $\mathbf{4}$ & $\mathbf{5}$ & $\mathbf{6}$ & $\mathbf{7}$ & $\mathbf{8}$ \\
\hline 1. Cognitive Approach & - & & & & & & \\
2. Behavioral Approach & .10 & - & & & & & \\
3. Cognitive Avoidance & $-.13^{*}$ & $.31^{* *}$ & - & & & & \\
4. Behavioral Avoidance & $-.26^{*}$ & $.13^{*}$ & $.13^{*}$ & - & & & \\
5. Task Value & $.31^{* *}$ & -.02 & -.11 & $-.17^{* *}$ & & & \\
6. Attention & $.27^{* *}$ & .05 & -.06 & $-.28^{* *}$ & $.29^{* *}$ & - & & \\
7. Enjoyment & $.37^{* *}$ & $.13^{*}$ & -.05 & $-.24^{* *}$ & $.55^{* *}$ & $.53^{* *}$ & - & \\
8. Boredom & $-.30^{* *}$ & -.00 & .10 & $.39^{* *}$ & $-.39^{* *}$ & $-.62^{* *}$ & $-.59^{* *}$ & - \\
\hline \multicolumn{1}{c}{ Note: $* \mathrm{p}<.05 ; * * \mathrm{p}<.01$} & & & & & & &
\end{tabular}

\section{DISCUSSION}

The research objectives consisted in assessing the psychometric properties of the BCS-AR. More specifically, internal consistency was evaluated through Cronbach's alpha; the scale's internal structure was assessed by confirmatory factor analysis; and evidence regarding criterion validity was provided by bivariate correlations. The study results are discussed below.

\section{Scales Correlations and Reliability}

Cognitive approach yielded a negative correlation with cognitive avoidance as well as behavioral avoidance; though it did not yield correlations with behavioral approach. On that regard, behavioral approach yielded a positive and significant correlation with both avoidance scales (Table 1). In Nett et al. study (2010), a similar correlation pattern was found. According to the authors, these relations could be explained by the boredom locus concept. The boredom source's perception could determine the implementation of certain strategies. In this line of thought, students who use cognitive approach strategies perceive boredom as an outcome of internal processes, which explains why they tend to make a positive reappraisal of the activity. On the contrary, students who use behavioral approach, cognitive avoidance and behavioral avoidance strategies, perceive it as an outcome which arises from an external factor (inadequate teaching method or task's features), which explains their efforts to change the external situation by proposing alternatives to the task or 
by placing their attention focus on something else.

Internal consistency analyses yielded acceptable results for cognitive approach, behavioral approach and cognitive avoidance scales, and excellent results for behavioral avoidance scale (George \& Mallery, 2003). As in Tze's study (2011), cognitive avoidance scale presented the lowest internal consistency value.

In order to improve consistency for the cognitive-avoidance scale, items were analyzed about their adequacy for university students. In Nett et al. study (2010), which was carried out with primary students, cognitive avoidance is measured using items such as "I do my homework" or "I study for next class". It is possible that these items do not reflect the university students' tendency to cognitively avoid a boring situation. This topic will be addressed in more detail during the discussion of the validity analysis results.

\section{Validity Analysis: Internal Structure}

The goodness of fit for the three models of boredom-coping strategies was assessed through confirmatory factor analysis. These were the before mentioned unidimensional, hierarchical an oblique models (Figure 1). The aim was to replicate the model of analysis implemented by Nett et al. (2010) so as to provide an accurate comparison. Nevertheless, analysis for goodness-of-fit turned out unsatisfactory for all three models. Modification indexes suggested a correlation between the same item's measuring errors in both, hierarchical and oblique models. As item's measuring errors account for the combined effect of any source of influence besides the specified factors (Arias, 2008), some elements not specified in the model could be affecting the participants' answers. When reviewing those items, significant content overlap was found in their wording. This redundancy could allow unspecified factors (e.g., age, cultural context) to bring about item variations for which coping strategies are not accountable.

Research by Tze and colleagues (Tze, 2011; Tze et al., 2013) reveals that cultural factors (e.g. cultural values) could determine the choice for a certain type of boredom coping strategy.

It is also possible that participants' attitudes towards learning, ways of approaching boredom or class characteristics influenced their answers. For example, questionnaires were administered in practical and theoretical classes, which differ in levels of difficulty, effort and participation required form students; therefore, this situation could indirectly affect 
their scoring.

It is important to note that correlated errors were referred to items within the same scales, and there were no correlations between items in different scales. With some caution, we could assert that re-specifications point to item's wording, although other potential sources of influence are not discarded. Tze's study (2011) also supports this claim, as the author also applied re-specifications to the oblique model in both Chinese and Canadian samples; attributing this decision to item's content similarity.

In accordance with these thoughts, the pertinent re-specifications were made obtaining a significant improvement in goodness-of fit for all three proposed models. Even so, as it had been found in previous studies, the oblique model showed best goodness-of-fit indexes (see Table 2); the same as in other studies (Eren, 2013; Nett et al., 2010; Tze, 2011).

Finally, it is worth mentioning that the re-specified hierarchical model showed satisfactory goodness of fit indexes, as well. Consequently, it could also be used to assess boredom coping strategies, while supporting the existence of a general factor which accounts for all four strategies.

\section{Validity analysis: Criterion Validity}

In general terms, it was found that cognitive approach, behavioral approach, and cognitive avoidance strategies were moderate predictors of attention, boredom, enjoyment and task value, with varying degrees of influence.

Cognitive approach presented a positive correlation with attention, enjoyment, and task value. These results coincide with those reported by Nett et al. (2010), which informed positive relations among this strategy and not only enjoyment but also effort and interest. On the other hand, in both, the present study and Nett's research, cognitive approach shows a negative correlation with boredom. Findings support the claim that this type of strategy proves to be the most adaptive, since it predicts positive academic results. Cognitive approach strategies' main characteristic is an emphasis in activity's positive reappraisal. The student carries out a cognitive effort to find positive value about the situation. A student aware of her own perception on task value finds the material useful and relevant and her attention is focused, as she attempts to understand (Sánchez Rosas et al., in press). Besides, these strategies play a key role in student's engagement in class, since they mediate between 
perceived instrumentality (value) and diverse engagement aspects (agentic, behavioral, emotional and cognitive) (Eren, 2013).

As soon as the student becomes conscious of the fact that the material is useful to achieve his future goals; he will be able to deal with boredom by revaluating the situation (reminding him-self about the class' relevance) and compromising with activities in various ways. Finally, when people, and in particular students, are engaged in activities regarded as important, they tend to experience more joy and feel more proud and satisfied (Goetz, Frenzel, Stoeger, \& Hall, 2010). This would reduce boredom and increase enjoyment and performance.

Cognitive avoidance yielded a positive correlation with boredom, as it did in Nett et al. study (2010), and a negative correlation with enjoyment, attention and task value. These strategies could be the less adaptive ones, since they predict negative academic results. Behavioral avoidance strategies are characterized by the student's efforts to evade a boring situation, paying attention to other more interesting stimuli.

Cognitive avoidance yielded a positive correlation with boredom, as it did in Nett et al. study (2010), and a negative correlation with enjoyment, attention and task value. These strategies could be the less adaptive ones, since they predict negative academic results. Behavioral avoidance strategies are characterized by the student's efforts to evade a boring situation, paying attention to other more interesting stimuli. When a student finds an activity of little use, not interesting or relevant (i.e. lack of value), they experience boredom, and, in their effort to mitigate this emotion, they could try looking for more rewarding stimuli. Then they could make use of behavioral avoidance strategies, for instance, talking to a classmate, diverting their attention from the subject or focusing it on an activity unrelated to the class. Attention is an important cognitive resource to successfully perform in achievement contexts, and if it is focused on something different to the material, it impairs learning, and consequently, jeopardizes the student's good performance.

Behavioral approach had no correlation with task value, boredom and attention, and showed a positive correlation with enjoyment. In Nett et al. study (2010), a reverse pattern is observed: this strategy held a positive correlation with boredom, and a zero correlation with enjoyment. As regards this matter, in Eren's study (2013) behavioral approach correlated with agentic engagement. Agentic engagement is understood as the active 
contribution the students can make when going beyond the instruction they receive by personalizing it and by enhancing both the lesson and the conditions under which they learn (Reeve \& Tseng, 2011). This might mean that students who modify their boring situation, for instance, by providing alternatives for a required task, are more engaged in it and, subsequently, they experience more enjoyment.

Cognitive avoidance strategies did not show any significant correlation with any criterion variable. No correlation with boredom was also reported in Tze (2011), in both, Canadian and Chinese samples. These results, in addition to Cronbach's alpha, point out difficulties with item's content for this subscale. More specifically, there might be possible that this subscale does not assess the construct it's aimed for. In Nett and colleagues' (2010) study, cognitive avoidance in a strategy used to escape from a boring situation by making use of cognitive resources. Attention is conceived as an attribute that, diverted from the present academic situation, (i.e. the boring class), is directed to a different situation, also characterized by being academic. Items such as I do my homework or I get ready for next class represent cognitive avoidance in the original study. It is justifiable to ask to what extent university students turn to this type of activities when bored in class. If these items were to be assessed in a sample of students different from the original population, contextual and developmental variables would play a key role; these factors would be decisive to the answers provided, but they were not taken into account in Nett et al. (2010). The original study's sample comprised primary school students, while the present study was focused on university students. The following question arises: if university students focused their attention on a topic unrelated to the class, wouldn't they be employing cognitive avoidance strategies? Do Argentinian university students react in a cognitive and avoiding way, different from the original population? There might be a set of items suitable to better assess cognitive avoidance strategies for university students within the Argentinean culture. Some examples are: I think about a film I've just watched, "I think I want to be in a different place or I plan what to do during my free time. This assumption should be tested, and so it remains for further studies to develop suitable items taking context and population characteristics into account, and evaluate if those items adequately address the chosen sample.

Finally, bivariate correlations among criterion variables support this study's assumptions. It was highly expected for boredom to show a negative correlation with task 
value and enjoyment, while it was also expected for task value and enjoyment to present a strong positive correlation. Pekrun's theory (2006) supports this assertion, firstly because boredom and enjoyment are opposite emotions; and secondly because boredom arises from lack of value. As the results show, whenever students find personal value on an activity, boredom decreases and enjoyment grows. Besides this, provided that students find a subject interesting and useful, they will be willing to engage more in the activity, which would mean an increase in their attentional resources.

In summary, this research analyzed the bivariate relationship of coping with boredom to task value, attention, boredom, and enjoyment. However, further research could explore other self-regulated learning strategies (Furlan, Sánchez Rosas, Heredia, Piemontesi, \& Illbele, 2009; Sánchez Rosas \& Pérez, 2015; Wolters \& Benzon, 2013) or coping strategies (Piemontesi, Heredia, Furlan, Sánchez, \& Martínez, 2012), and different control-value appraisals such as achievement goals (Sánchez Rosas, 2015b) and selfefficacy Rey, Blasco, \& Borrás, 2000). In addition, these results should be interpreted cautiously as the analysis showed up relations, but not their directions. Given this procedures it is not possible to discern what comes first (for example, the avoidance strategy and after this, the attention loss), thus results does not imply causality. More sophisticated statistic method, such as path analysis (Pérez, Medrano, \& Sánchez Rosas, 2013), could be employed in analyzing relationships between coping with boredom and their antecedent and outcome variables.

\section{CONCLUSIONS}

The strategies implemented by students in order to cope with boredom have received little attention and they represent a field in research that has recently been addressed. Based on the psychometric studies carried out, and in light of the discussions arising from them and previous studies, it can be stated that the validation for the Boredom Coping Scales questionnaire was successfully accomplished. This instrument has proven to be effective in assessing in which manner students respond to boredom in class.

The aim of this study is to make a contribution to the boredom coping strategies research field, by providing a first validation of this questionnaire in Spanish, and making it possible to compare results with other studies, which adds to the theoretical, empirical and technical corpus in educational psychology. 


\section{REFERENCES}

Acee, T. W., Kim, H., Kim, H. J., Kim, J., Chu, H. N. R., Kim, M., Cho, Y., \& Wicker, F. (2010). Academic Boredom in Under- and Over-Challenging Situations. Contemporary Educational Psychology, 35, 17-27. doi:10.1016/j.cedpsych.2009.08.002

Albright, J. J., \& Hun M. P. (2009).Confirmatory Factor Analysis Using Amos, LISREL, Mplus, and SAS/STAT CALIS. Working Paper. The University Information Technology Services (UITS) Center for Statistical and Mathematical Computing, Indiana University.

Arbuckle, J. L. (2010). IBM SPSS Amos 19 User's Guide. Chicago, IL: IBM.

Arias, B. (2008). Desarrollo de un Ejemplo de Análisis Factorial Confirmatorio con LISREL, AMOS y SAS. Seminario de Actualización en Investigación sobre Discapacidad SAID 2008. University of Valladolid.

Aron, A., \& Aron, E. (2001). Estadística para psicología. Buenos Aires: Prentice Hall. Daschmann, E. C., Goetz, T., \& Stupinsky R. H. (2012). Exploring the Antecedents of Boredom: Do Teaches Know Why Their Students Are Bored? S/D.

De Castro Marzo, D. (2011). Construcción y Análisis de Fiabilidad y Validez de un Test de Medida de Imaginación y Comprobación de los Factores que la componen. University of Zaragoza, Spain.

Eccles, J. S. (2005). Subjective task value and the Eccles et al. model of achievement-related choices. In A. J. Elliot \& C. S. Dweck (Eds.), Handbook of competence and motivation (pp. 105-121). New York, NY: Guilford Press.

Elliot, A. J. (1999). Approach and avoidance motivation and achievement goals. Educational Psychologist, $34,149-169$.

Eren, A. (2013). Prospective Teachers' Perceptions of Instrumentality, Boredom Coping Strategies, and Four Aspects of Engagement. Teaching Education, 24(3), 302-326. doi:10.1080/10476210.2012.724053

Farmer, R., \& Sundberg, N. D. (1986). Boredom Proneness-The Development and Correlates of a New Scale. Journal of Personality Assessment, 50(1), 4-17.

Figueroa, M., \& Cohen Imach, S. (2006). Estrategias y Estilos de Afrontamiento del Estrés en Adolescentes. En E. N. Contini de González (comp.). Pensar la adolescencia hoy. De la psicopatología al bienestar psicológico (pp. 29-52). Buenos Aires: Paidós.

Frias Jimenez, R. A., Arias, M. G., \& González Laucirica, A. M. (2013). Metodología de Validación de Gestión del Cliente Interno en Procesos Empresariales. S/D.

Furlan, L., Sánchez Rosas, J., Heredia, D., Piemontesi, S., \& Illbele, A (2009). Estrategias de aprendizaje y ansiedad ante los exámenes en estudiantes universitarios. Pensamiento psicológico, 5(12), 117-124.

George, D., \& Mallery, P. (2007). SPSS for Windows step by step: A simple guide and reference. 11.0 update (7th ed.). Boston: Allyn \& Bacon.

Goetz, T., Frenzel, A. C., Stoeger, H., \& Hall, N. C. (2010). Antecedents of everyday positive emotions: an experience sampling analysis. Motivation and Emotion, 34(1), 49-62. doi:10.1007/s11031-009-91522

Goetz, T., Ludtke, O., Nett U. E., Keller, M. M., \& Lipnevich, A. A. (2013). Characteristics of Teaching and 
Students' Emotions in the Classroom: Investigating Differences Across Domains. Contemporary Educational Psychology, 38(4).383-394. doi:10.1016/j.cedpsych.2013.08.001

Goetz, T., \& Nett, U. E. (2008). Coping with boredom scales. Codebook of the Coping with Boredom Scales. Math related version. Empirical Educational Research, University of Konstanz / Thurgau University of Teacher Education.

Goetz, T., Pekrun, R., Hall, N., \& Haag, L. (2006). Academic emotions from a social-cognitive perspective: antecedents and domain specificity of students' affect in the context of Latin instruction. British Journal of Educational Psychology, 76(2), 289-308. doi:10.1348/000709905X42860

González, A., Donolo, D., \& Rinaudo, C. (2009). Emociones Académicas en Universitarios: Su Relación con las Metas de Logro. Ansiedad y Estrés, 15(2), 263-277.

González, A., Paolini, V., \& Rinaudo, C. (2013). Aburrimiento y disfrute en clase de lengua española en secundaria: predictores motivacionales y efectos sobre el rendimiento.

Anales de Psicología, 29(2), 426-434. doi:10.6018/analesps.29.2.136401 Hair, J., Anderson, R., Tatham, R., \& Black, W. (1999). Análisis Multivariante. $5^{\mathrm{a}}$ ed. Prentice Hall: Madrid, Spain.

Holahan, C. J., Moos, R. H., \& Schaefer, J. A. (1996). Coping, stress resistance, and growth: Conceptualizing adaptive functioning. In M. Zeidner \& N. S. Endler (Eds.), Handbook of coping. Theory, research, applications. New York: John Wiley \& Sons, Inc.

Hu, L. T., \& Bentler, P. M. (1998). Fit indices in covariance structure modeling: Sensitivity to underparameterized model misspecification. Psychological Methods, 3(4), 424-453.

Lazarus, R., \& Folkman, S. (1985). If It Changes It Must Be a Process: Study of Emotion and Coping During Three Stages of a College Examination. Journal of Personality and Social Psychology, 48(1), 150170.

Mann, S., \& Robinson, A. (2009). Boredom in the lecture theatre: an investigation into the contributors, moderators and outcomes of boredom amongst university students. British Educational Research Journal, 35(2), 243-258. doi:10.1080/10476210.2012.01411920802042911

Martinez Ortega, R. M., Tuya Pendás, L. C., Martinez Ortega, M., Pérez Abreu, A., \& Cánovas, A. M. (2009). El coeficiente de Correlación de los Rangos de Spearman, Caracterización. Revista Habanera de Ciencias Médicas, 8(2), 1-19.

Massingham, P., \& Herrington, T. (2006). Does Attendance Matter? An Examination of Student Attitudes, Participation, Performance and Attendance. Journal of University Teaching \& Learning Practice, 3(2), 83-103.

Nett, U. E., Goetz, T., \& Daniels, L. M. (2010). What to do when feeling bored? Students strategies for coping with boredom. Learning and Individual Differences, 20, 626-638. doi:10.1016/j.lindif.2010.09.004

Pekrun, R. (1992). The Impact of Emotions on Learning and Achievement: Towards a Theory of Cognitive/Motivational Mediators. Applied Psychology: An International Review, 41(4), 359-376.

Pekrun, R. (1993). Facets of students' academic motivation: A longitudinal expectancy-value approach. In M. L. Maehr \& P. R. Pintrich (Eds.), Advances in motivation and achievement, 8, 139-189.

Pekrun, R. (2006). The control-value theory of achievement emotions: assumptions, corollaries, and 
Implications for Educational Research and Practice. Educational Psychology Review, 18(4), 315341. doi:10.1007/s10648-006-9029-9

Pekrun, R., Elliot, A. J., \& Maier, M. A. (2006). Achievement goals and discrete achievement emotions: A theoretical model and prospective test. Journal of Educational Psychology, 98(3), 583-597. doi:10.1037/0022-0663.98.3.583

Pekrun, R., Goetz, T., Daniels, L. M., Stupinsky, R. H., \& Perry, R. P. (2010). Boredom in achievement settings: exploring Control-Value antecedents and performance outcomes of a neglected emotion. Journal of Educational Psychology, 102(3), 531-549. doi:10.1037/a0019243

Pekrun, R., Goetz, T., Frenzel, A., Barchfeld, P., \& Perry, R. (2011). Measuring Emotions in Students` Learning and Performance: The Achievement Emotions Questionnaire (AEQ). Contemporary Educational Psychology, 36, 36-48. doi:10.1016/j.cedpsych.2010.10.002

Pekrun, R., Goetz, T., Titz, W., \& Perry, R. P. (2002). Academic emotions in students' self-regulated learning and achievement: A program of qualitative and quantitative research. Educational psychologist, 37(2), 91-105. doi:10.1207/S1532698EP3702_4

Pekrun, R., \& Stephens, E. J. (2010). Achievement Emotions: A Control-Value Approach. Social and Personality Psychology Compass, 4(4), 238-255. doi:10.1111/j.1751-9004.2010.00259.x

Pérez-Gil, J., Chacón Moscoso, S., \& Moreno Rodríguez, R. (2000). Validez de Constructo: el Uso de Análisis Factorial Exploratorio-Confirmatorio Para Obtener Evidencias de Validez. Psicothema, $12(2), 442-446$.

Pérez, E., Medrano, L., \& Sánchez-Rosas, J. (2013). El path analysis: conceptos básicos y ejemplos de aplicación. Revista de la Asociación Argentina de Ciencias del Comportamiento, 5, 52-66.

Perry, R. P., Hladkyj, S., Pekrun, R., \& Pelletier, S. (2001). Academic Control and Action Control in the Achievement of College Students: A Longitudinal Field Study. Journal of Educational Psychology, 93(4), 776-789. doi:10.1037//OO22-0663.93.4.776

Piemontesi, S., Heredia, D., Furlan, L., Sánchez, J., \& Martínez, M. (2012). Ansiedad ante los exámenes y estilos de afrontamiento ante el estrés académico en estudiantes universitarios. Anales de Psicología, 28(1), 89-96.

Pintrich, P. R., Smith, D. A. F., García, T., \& McKeachie, W. J. (1993). Reliability and predictive validity of the motivated strategies for learning questionnaire (MSLQ). Educational and Psychological Measurement, 53, 810-814.

Reeve, J., \& Tseng, C. M. (2011). Agency as a fourth aspect of students' engagement during learning $\begin{array}{llll}\text { activities. } & \text { Contemporary } & \text { Educational }\end{array}$ doi:10.1016/j.cedpsych.2011.05.002

Rey, M., Blasco, T., \& Borrás, X. (2000). Efectos de un procedimiento de inducción de estados de ánimo sobre la autoeficacia. Anales de Psicología, 16, 23-31.

Rosegard, E., \& Wilson, J. (2013).Capturing Students`Attention: An Empirical Study. Journal of the Scholarship of Teaching and Learning, 13(5), 1-20.

Sánchez Rosas, J. (2015a). The Achievement Emotions Questionnaire-Argentine (AEQ-AR): internal and 
external validity, reliability, gender differences and norm-referenced interpretation of test scores. Evaluar, 41-74.

Sánchez Rosas, J. (2015b). Validation of the Achievement Goal Questionnaire - Revised in Argentinean university students (A-AGQ-R). International Journal of Psychological Research, 8(1), 10-23.

Sánchez Rosas, J., \& Pérez, E. (2015). Measuring threats, benefits, emotional costs and avoidance of academic help seeking in Argentinian university students. Pensamiento Psicológico, 13(2), 49-64. doi:10.11144/Javerianacali.PPSI13-2.mtbe

Sánchez Rosas, J., Piotti, A., Sánchez, V., Pereira, A., \& Debat, E. (2011). Implicancias del interés, la importancia y la utilidad de los materiales y contenidos de aprendizaje para las emociones académicas. Presented at the III Congreso de Psicología de la Facultad de Psicología de la Universidad Nacional de Córdoba, Argentina.

Sánchez-Rosas, J., Takaya, P. B., \& Molinari, A. V. (2016). The Role of Teacher Behavior, Motivation and Emotion in Predicting Academic Social Participation in Class. Pensando Psicología, 12(19), 39-53. doi: http://dx.doi.org/10.16925/pe.v12i19.1327

Sánchez-Rosas, J., Takaya, P. B., \& Molinari, A. V. (in press). Atención en clase: rol predictivo del comportamiento docente, valor de la tarea, autoeficacia, disfrute y vergüenza. Psiencia. Revista Latinoamericana de Ciencia Psicológica.

Tze, M. C. (2011). Investigating Academic Boredom in Canadian and Chinese Students. Thesis for the degree of Master of Education in Psychological Studies in Education. Department of Educational Psychology.University of Alberta. Edmonton. Canada.

Tze, M. C., Daniels, L. M., \& Klassen, R. M. (2015). Evaluating the Relationship Between Boredom and Academic Outcomes: A Meta-Analysis. Educational Psychological Review. 1-26. doi:10.1007/s10648-015-9301-y

Vázquez Valverde, C., Crespo Lòpez, M., \& Ring, J. (2000). Estrategias de afrontamiento. En A. Bulbena, G. Berrios y Fernández de Larrinoa, P. (Eds), Medición clínica en Psiquiatría y Psicología (pp. 425446). Barcelona: Masson.

Vodanovich, S. J., Weddle, C., \& Piotrowski, C. (1997).The relationship between boredom proneness and internal and external work values. Social Behavior and Personality, 25, 259-264.

Vogel-Walcutt, J.J., Fiorella, L., Carper, T., \& Schatz, S. (2011).The definition, assessment, and mitigation of state boredom within educational settings. Educational Psychology Review, 24, 89-111. doi:10.1007/s10648-011-9182-7

Weiner, B. (1985). An attributional Theory of Achievement Motivation and Emotion. Psychological Review, 92(4), 548-573.

Wolters, C. A., \& Benzon, M. B. (2013). Assessing and predicting college students' use of strategies for the self-regulation of motivation. The Journal of Experimental Education, 81(2), 199-221. doi: $10.1080 / 00220973.2012 .699901$

Wood, A. M. (1998). The Effects of teacher enthusiasm on student motivation, selective attention and text memory. Thesis for the degree of Doctorate of Philosophy. Department of Psychology. The University of Western Ontario, Canada. 


\section{APPENDIX \\ The Boredom Coping Scales-Argentine (BCS-AR): Instructions and scales}

El siguiente cuestionario mide las estrategias de afrontamiento del estudiante al experimentar aburrimiento en clase. Las estrategias de afrontamiento refieren a las acciones que lleva a cabo el alumno para mitigar esta emoción. Lee cuidadosamente y responde indicando el grado de acuerdo con aquello que describe cada ítem en una escala de 1 (nada de acuerdo) a 5 (totalmente de acuerdo).

"Cuando estoy aburrido en clases de esta materia..."

\begin{tabular}{|c|c|c|c|c|}
\hline Item & APROXIMACIÓN COGNITIVA & $\mathbf{M}$ & SD & rit \\
\hline $\mathrm{ApCog} 1$ & Trato de prestar más atención a la clase. & 3.84 & 0.92 & .49 \\
\hline $\mathrm{ApCog} 2$ & Me obligo a concentrarme nuevamente. & 3.82 & 0.93 & .44 \\
\hline $\mathrm{ApCog} 3$ & Me concientizo de la importancia del tema. & 3.76 & 0.95 & .49 \\
\hline ApCog4 & Trato de concientizarme de la importancia de esta materia. & 4.00 & 0.96 & .46 \\
\hline $\mathrm{ApCog} 5$ & Me obligo a concentrarme nuevamente porque el tema es importante. & 3.78 & 0.89 & .59 \\
\hline \multicolumn{5}{|c|}{ APROXIMACIÓN CONDUCTUAL } \\
\hline ApCon1 & Le pregunto al profesor si podemos hacer alguna otra cosa. & 1.41 & 0.65 & .54 \\
\hline ApCon2 & Le pido al profesor que nos dé tareas más interesantes. & 1.64 & 0.82 & .64 \\
\hline ApCon3 & Sugiero que el profesor prepare clases más variadas. & 1.72 & 0.92 & .64 \\
\hline ApCon4 & Intento sacar del tema al profesor para que discutamos sobre un asunto que me interese. & 1.70 & 0.93 & .50 \\
\hline ApCon5 & Saco a colación algún tema que creo les interesa más a mis compañeros. & 1.83 & 0.95 & .52 \\
\hline \multicolumn{5}{|c|}{ EVITACIÓN COGNITIVA } \\
\hline EvCog1 & Me preparo para la próxima clase. & 2.80 & 1.17 & .44 \\
\hline $\mathrm{EvCog} 2$ & Hago la tarea. & 2.95 & 1.19 & .50 \\
\hline $\mathrm{EvCog} 3$ & Estudio para otra materia. & 2.40 & 1.23 & .55 \\
\hline $\mathrm{EvCog} 4$ & Pienso en la tarea o en algo que tengo que estudiar. & 3.24 & 1.17 & .39 \\
\hline EvCog5 & Copio la tarea para la próxima clase. & 3.11 & 1.33 & .36 \\
\hline \multicolumn{5}{|c|}{ EVITACIÓN CONDUCTUAL } \\
\hline EvCon1 & Hablo con la persona que está sentada a mi lado. & 3.29 & 1.25 & .75 \\
\hline EvCon2 & Empiezo a hablar con el compañero de clase que está sentado a mi lado. & 3.03 & 1.35 & .85 \\
\hline EvCon3 & Me distraigo interactuando con mi compañero de clase. & 2.85 & 1.27 & .88 \\
\hline EvCon4 & Intento contactarme con otros compañeros de clase que también se están aburriendo. & 2.42 & 1.27 & .70 \\
\hline EvCon5 & Me entretengo con mi compañero/a de banco o con alguien que esté sentado/a cerca & 2.68 & 1.27 & .83 \\
\hline
\end{tabular}

